\title{
Geochemical tracing and modeling of surface and deep water- rock interactions in elementary granitic watersheds (Strengbach and Ringelbach CZOs, France)
}

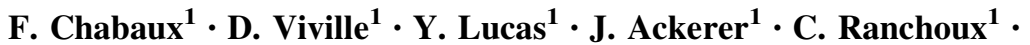

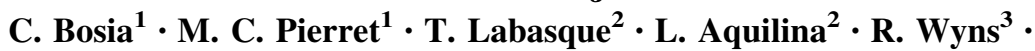 \\ C. Lerouge $^{3} \cdot$ C. Dezaye ${ }^{3} \cdot$ P. Négrel $^{3}$
}

Received: 7 April 2017/Revised: 17 April 2017/Accepted: 17 April 2017/Published online: 13 May 2017

(C) The Author(s) 2017. This article is an open access publication

\begin{abstract}
From the study of the Strengbach and Ringelbach watersheds we propose to illustrate the interest of combining the geochemical tracing and geochemical modeling approaches on surface and deep borehole waters, to decipher the diversity of the water flow and the associated water-rock interactions in such elementary mountainous catchments. The results point to a clear geochemical typology of waters depending on the water circulations (deep vs. hypodermic) within the substratum.
\end{abstract}

Keywords Weathering - Water pathways - U activity ratios $\cdot \mathrm{Sr}$ isotope ratios $\cdot$ Anthropogenic gases (CFC, SF6) $\cdot$ CZO

\section{Introduction}

Understanding the diversity of water pathways and of related water-rock interactions, is a key issue for Earth surface sciences to correctly describe and model the geochemical functioning of the Critical Zone (CZ). It is also a major issue to predict the $\mathrm{CZ}$ evolution in response to environmental modifications due to tectonic, climatic or

11th International Symposium on Geochemistry of the Earth's Surface.

F. Chabaux

fchabaux@unistra.fr

1 Laboratoire D'Hydrologie et de Géochimie de Strasbourg (LHyGeS), CNRS, Université de Strasbourg, 1 Rue Blessig, 67084 Strasbourg Cedex, France

2 CNRS, Géosciences Rennes UMR 6118 Université de Rennes1, Campus de Beaulieu, 35042 Rennes Cedex, France

3 BRGM, 3 Avenue Claude Guillemin, 45060 Orléans, France anthropogenic forcings (e.g., Banwart et al. 2011; Brantley et al. 2007). Such a characterization and understanding first requires the recognition and the investigation of different hydrological compartments involved in the water circulations.

In elementary watersheds, especially in mountain context, current studies show that in addition to hypodermic circulations more or less parallel to the slopes of the basins and feeding the springs, there are deeper circulations through fractures affecting the bedrock (e.g., Schaffhauser et al. 2014). The Strengbach and Ringelbach experimental watersheds, located in eastern France, equipped with semideep boreholes up to $100-150 \mathrm{~m}$ depth, make it possible to carry out hydrogeological and hydrogeochemical investigations. Such studies bring new information on the nature of weathering processes involved and their relationships with the water circulation contexts. In this paper we present the first results of these studies.

\section{Site description-analytical procedures- geochemical modeling approach}

The Ringelbach $\left(0.36 \mathrm{~km}^{2}\right)$ and Strengbach $\left(0.8 \mathrm{~km}^{2}\right)$ watersheds are granitic catchments that have been equipped as hydro-geochemical observatories, or Critical Zone Observatories (CZO) since 1976 for the Ringelbach basin and since 1986 for the Strengbach catchment (http://ohge. u-strasbg.fr). More details can be found in Gangloff et al. (2014), Pierret et al. (2014), Prunier et al. (2015) for the Strengbach CZO and in Schaffhauser et al. (2014) for the Ringelbach CZO. Several permanent springs of small size drain the granitic part of the two catchments. They have been regularly sampled to analyze the geochemical and isotopic compositions of their waters (Pierret et al. 2014; 
Schaffhauser et al. 2014). Both watersheds are also equipped with boreholes, which have confirmed the occurrence of deep circulations in the two watersheds along fractures concentrated in relatively narrow layers, several centimeters wide. Such observations suggest that deep waters in the two watersheds circulate in a network of more or less independent conduits, which could reach a depth of several tens to hundreds of meters. In the present study, these boreholes have allowed us to sample deepwaters down to a depth of $150 \mathrm{~m}$ for the Ringelbach site and of $50 \mathrm{~m}$ for the Strengbach one (see Fig. 1 for the location of the boreholes and springs used for this study).

Several of the spring and borehole water samples were analyzed for determining their major and trace element concentrations and their ${ }^{87} \mathrm{Sr} /{ }^{86} \mathrm{Sr}$ isotope and $\left({ }^{234} \mathrm{U} /{ }^{238} \mathrm{U}\right)$ activity ratios. These analyzes were performed following the standard procedures commonly used in the laboratory (see details in Schaffhauser et al. 2014 for summary). The data have been partly presented and discussed in previous works (Prunier 2008; Pierret et al. 2014; Schaffhauser 2013; Schaffhauser et al. 2014), which have emphasized the interest of coupling various geochemical tracers to constrain the main (bio)-geochemical processes involved in the $\mathrm{CZ}$ functioning. The multi-component reactive transport model KIRMAT (KInetic Reactions and MAss transport) has been also applied to constrain the main water-rock interactions controlling the chemical composition of the Strengbach and Ringelbach spring and borehole waters (Schaffhauser 2013; Ackerer 2017). The code KIRMAT solves the geochemical reaction and transport mass balance equations in a saturated porous medium. A description of its functionalities can be found in Lucas et al. (2010). Lastly, a few spring and borehole samples from the Strengbach catchment have been collected for groundwater dating by the analysis of anthropogenic gases (CFC, SF6), following the techniques detailed in Labasque et al. (2014). This approach leads to the determination of the groundwater recharge year, and thus to the groundwater apparent age. The combined use of these different approaches makes it possible to better specify the origin of the geochemical differences that the data point out between the surface and the deep-borehole waters.

\section{Results and implications}

Whether for the Strengbach or the Ringelbach watersheds, the geochemical data of the deep borehole waters show geochemical and isotopic compositions that are distinctly $\begin{array}{llll}0.71 & 0.72 & 0.73 & 0.74\end{array}$
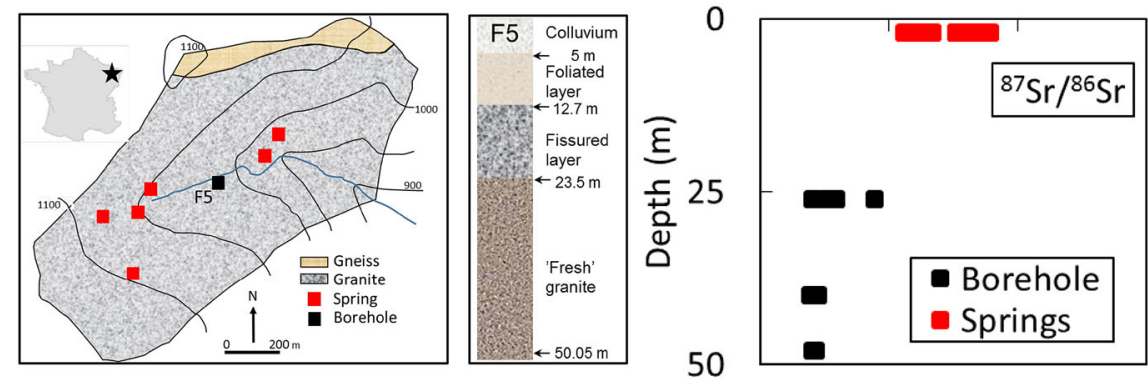

0.71

0.72

0.73

0.74
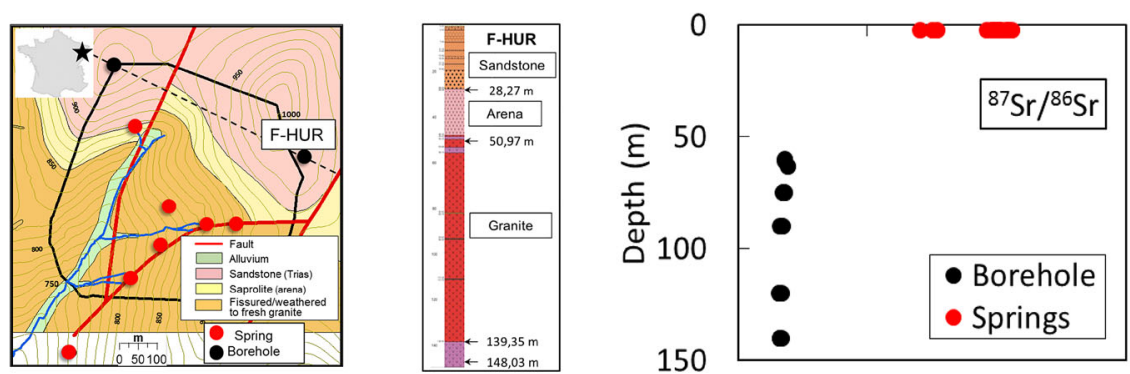

\section{$\begin{array}{lllll}0.7 & 1 & 1.3 & 1.6 & 1.9\end{array}$}

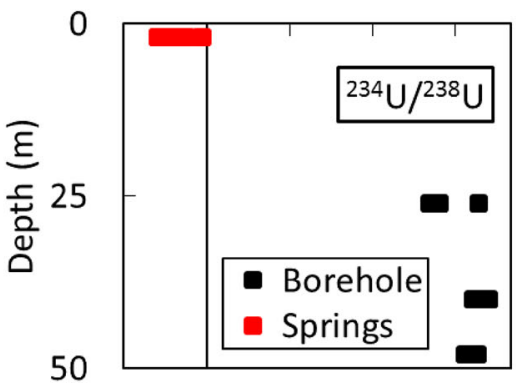

$\begin{array}{lllll}0.7 & 1 & 1.3 & 1.6 & 1.9\end{array}$

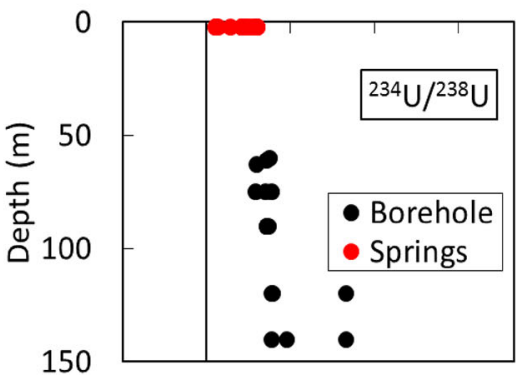

Fig. 1 Maps of the watersheds, profiles of the boreholes used in this study, variation of U and Sr isotopic ratios in spring and borehole waters for the two sites (top Strengbach; bottom Ringelbach). Both catchments are located on the eastern side of the Vosges massif (France) in a temperate oceanic-mountainous climate with a mean annual precipitation of $1400 \mathrm{~mm}$ and a mean annual runoff of $814 \mathrm{~mm}$ for the Strengbach site (Viville et al. 2012), and of 1250 and of $600 \mathrm{~mm}$ respectively for the Ringelbach catchment (Ambroise 1995). For the latter one, the bedrock consists of Hercynian porphyritic granite capped in its upper part by a residual cover of Triassic sandstones. For the Strengbach catchment, the bedrock is a Ca-poor Hercynian granite, covered by a small band of gneiss along the catchment's northern edge 
Fig. 2 Piper diagrams for some spring and borehole waters from the two catchments

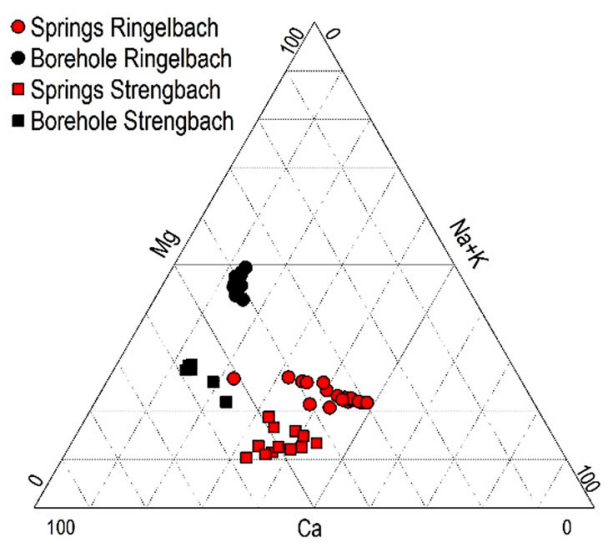

different from those of spring waters. As shown in Piper Diagrams (Fig. 2), the borehole waters are mostly $\mathrm{HCO}_{3}$ $\mathrm{Ca}$ water types, while spring waters are $\mathrm{Cl}-\mathrm{Na}$ waters, in addition to be more concentrated. The geochemical differences between the two water types are also seen with $U$ and $\mathrm{Sr}$ isotopic ratios. At both sites, the deep borehole waters have less radiogenic $\mathrm{Sr}$ isotopic ratios and higher $\mathrm{U}$ activity ratios than spring waters and borehole shallower waters (Fig. 1). Such differences in the $\mathrm{Sr}$ isotopes most likely result from different water-rock interactions controlled by different minerals depending on the water circulation context. For the Strengbach catchment a comparison of the $\mathrm{Sr}$ isotope ratios of water samples with the $\mathrm{Sr}$ ratios of the minerals from the granitic bedrock and the soils (data for minerals from Aubert et al. 2001, and Prunier et al. 2015) suggest a more significant contribution of minor primary minerals such as apatite in the $\mathrm{Sr}$ and $\mathrm{Ca}$ budget of deep waters and of clay minerals in the chemical budget of spring waters. The key role of clay minerals in the water-rock interactions controlling the geochemical budget of the Strengbach spring waters is confirmed by the numerical simulations performed with the KIRMAT hydro-geochemical code, which have additionally evidenced a strong coupling between the geochemical dynamics of clay minerals and apatite (Ackerer 2017). The KIRMAT simulations have also indicated that the residence time of the Strengbach spring waters are short, i.e. $\approx 3-5$ months, which is consistent with the time required to observe a nearly drying of the different springs during important drought events. Compared to the short residence times of the spring waters, the modeling of the hydrogeological functioning of Ringelbach watershed leads to much longer residence times in deep waters sampled in the boreholes of the two catchments (Schaffhauser 2013). The contrasted residence-times of spring and borehole waters are validated by the analyses of anthropogenic gases (CFC and SF6) of the Strengbach waters. The results give very variable residence times of the circulating waters in the Strengbach watershed, with ages of a few months for spring waters and ages exceeding several decades for the deep borehole waters (Viville et al. 2016). These differences confirm that the subsurface circulation systems are quite different from the deeper circulation ones. They also explain the contrasted $U$ activity ratios of these two water types. Due to alpha recoil and hence preferential leaching of ${ }^{234} \mathrm{U}$ during water-rock interactions, ${ }^{234} \mathrm{U}$ is usually enriched in the waters compared to its parent ${ }^{238} \mathrm{U}$ (e.g., Chabaux et al. 2008; DePaolo et al. 2012 and references therein). An increase in the water residence time within the bedrock due to a longer pathway, or a slower water velocity will thus logically result in an increase in the ${ }^{234} \mathrm{U}$ enrichment, i.e., of the $\mathrm{U}$ activity ratio of the water. Such a mechanism has been invoked to explain the moderate increase of the $\left({ }^{234} \mathrm{U} /{ }^{238} \mathrm{U}\right)$ activity ratios of the granitic spring waters with decreasing spring elevation in the Ringelbach catchment (Schaffhauser et al. 2014). The systematically higher $U$ activity ratios in the borehole waters than in the spring waters, with $\left({ }^{234} \mathrm{U} /{ }^{238} \mathrm{U}\right)$ ratios as high as 2 in the deep borehole waters of the Strengbach catchment (Fig. 1) is consistent with the long residence times deducted from the CFC and SF6 data. The occurrence of $\left({ }^{234} \mathrm{U} /{ }^{238} \mathrm{U}\right)$ ratios $<1$ in the Strengbach spring waters is common for the Strengbach catchment (Riotte and Chabaux 1999; Prunier 2008; Pierret et al. 2014). Such values are interpreted in terms of $U$ fluxes from previously weathered mineral phases, which agree with the idea that the water feeding these springs are supplied by subsurface waters. Moreover, the comparison of the geochemical and isotopic (U-Sr) compositions of the granitic spring waters with those of the borehole waters confirm a fairly high physical disconnection between the surface water supply network of the sources and the deeper one of the boreholes (Schaffhauser et al. 2014).

In conclusion, this study demonstrates the clear geochemical typology of waters in these two granitic catchments, according to the nature of water circulations (deep vs. hypodermic) within the substratum. Especially, it 
confirms the existence of relatively deep alteration processes, whose role in the functioning of the critical zone will have to be properly taken into account in future studies.

Acknowledgements This study was financially supported by funding from the CPER-Alsace REALISE program, the Equipex program CRITEX, the CNRS SOERE RBV and the LABEX "G-Eau-Thermie profonde". It also received funding from the French ANR Program under grant agreement ANR-15-CE06-0014 (Projet CANTAREAlsace).

Open Access This article is distributed under the terms of the Creative Commons Attribution 4.0 International License (http://crea tivecommons.org/licenses/by/4.0/), which permits unrestricted use, distribution, and reproduction in any medium, provided you give appropriate credit to the original author(s) and the source, provide a link to the Creative Commons license, and indicate if changes were made.

\section{References}

Ackerer J (2017) Mécanismes et taux de dénudation d'un bassin versant élémentaire (Strengbach, France) : apport de l'étude couplée des méthodes de datation isotopique (déséquilibres U-Th-Ra, 10Be in situ) et des méthodes de modélisation hydrogéochimique (KIRMAT). Thesis Ph.D. Université de Strasbourg, Strasbourg, France, p 200

Ambroise B (1995) Topography and the water cycle in a temperate middle mountain environment: the need for interdisciplinary experiments. Agric For Meteorol 73:217-235

Aubert D, Stille P, Probst A (2001) REE fractionation during granite weathering and removal by waters and suspended loads: $\mathrm{Sr}$ and $\mathrm{Nd}$ isotopic evidence. Geochim Cosmochim Acta 65:387-406

Banwart S, Bernasconi SM, Bloem J, Blum W, Brandao M, Brantley S, Zhang B (2011) Soil processes and functions in critical zone observatories: hypotheses and experimental design. Vadose Zone J 10:974-987

Brantley SL, Goldhaber MB, Ragnarsdottir KV (2007) Crossing disciplines and scales to understand the critical zone. Elements 3(5):307-314

Chabaux F, Bourdon B, Riotte J (2008) Chapter 3 U-series geochemistry in weathering profiles, river waters and lakes. In: Krishnaswami S, Cochran JK (eds) Radioactivity in the Environment. Elsevier, Amsterdam, pp 49-104

DePaolo DJ, Lee VE, Christensen JN, Maher K (2012) Uranium comminution ages: sediment transport and deposition time scales. C R Geosci 344:678-687
Gangloff S, Stille P, Pierret M-C, Weber T, Chabaux F (2014) Characterization and evolution of dissolved organic matter in acidic forest soil and its impact on the mobility of major and trace elements (case of the Strengbach watershed). Geochim Cosmochim Acta 130:21-41

Labasque T, Aquilina L, Vergnaud V, Barbecot F (2014) Interlaboratory comparison of the determination of sulfur hexafluoride (SF6) and three chlorofluorocarbons (CFC-11, -12 and -113) in groundwater and air standard. Appl Geochem 50:118-129

Lucas Y, Schmidt AD, Chabaux F, Clément A, Fritz B, Elsass Ph, Durand S (2010) Geochemcial tracing and hydrogeochemical modelling of water-rock interactions during salinization of alluvial groundwater (Upper Rhine valley, France). Appl Geochem 25:1644-1663

Pierret MC, Stille P, Prunier J, Viville D, Chabaux F (2014) Chemical and U-Sr isotopic variations in stream and source waters of the Strengbach watershed (Vosges mountains, France). Hydrol Earth Syst Sci 18:3969-3985

Prunier J (2008) Etude du fonctionnement d'un écosystème forestier en climat tempéré, par l'apport de la géochimie élémentaire et isotopique ( $\mathrm{Sr}, \mathrm{U}-\mathrm{Th}-\mathrm{Ra}$ ), Cas du bassin versant du Strengbach (Vosges, France), Thesis Ph.D. Université de Strasbourg, Strasbourg, France, p 303

Prunier J, Chabaux F, Stille P, Pierret MC, Viville D, Gangloff S (2015) Monitoring of geochemical and isotopic (Sr, U) signatures in soil solutions for the evaluation of soil weathering evolution (the Strengbach case). Chem Geol 417:289-305

Riotte J, Chabaux F (1999) $\left({ }^{234} \mathrm{U} /{ }^{238} \mathrm{U}\right)$ activity ratios in freshwaters as tracers of hydrological processes: the Strengbach watershed (Vosges France) Geochim. Cosmoch Acta 63:1263-1275

Schaffhauser T (2013) Traçage et modélisation des processus d'altération à l'échelle d'un petit bassin versant, le Ringelbach (Vosges, France) Ph.D. Thesis, Université de Strasbourg, Strasbourg, France, p 283

Schaffhauser T, Chabaux F, Ambroise B, Lucas Y, Stille P, Reuschlé T, Perrone T, Fritz B (2014) Geochemical and isotopic (U, Sr) tracing of water pathways in the granitic Ringelbach catchment (Vosges Mountains, France). Chem Geol 374-375:117-127

Viville D, Chabaux F, Stille P, Pierret MC, Gangloff S (2012) Erosion and weath- ering fluxes in granitic basins: the example of the Strengbach catchment (Vosges massif, eastern France). Catena 92:122-129

Viville D, Aquilina L, Ackerer J, Chatton E, Labasque T, Pierret MC, Granet M, Perrone T, Chabaux F (2016) Coupling groundwater residence time and ${ }^{234} \mathrm{U} /{ }^{238} \mathrm{U}$ isotopic ratios in a granitic catchment (Vosges, Eastern France). Geophysical Research Abstracts 18:EGU2016-EGU5757 